
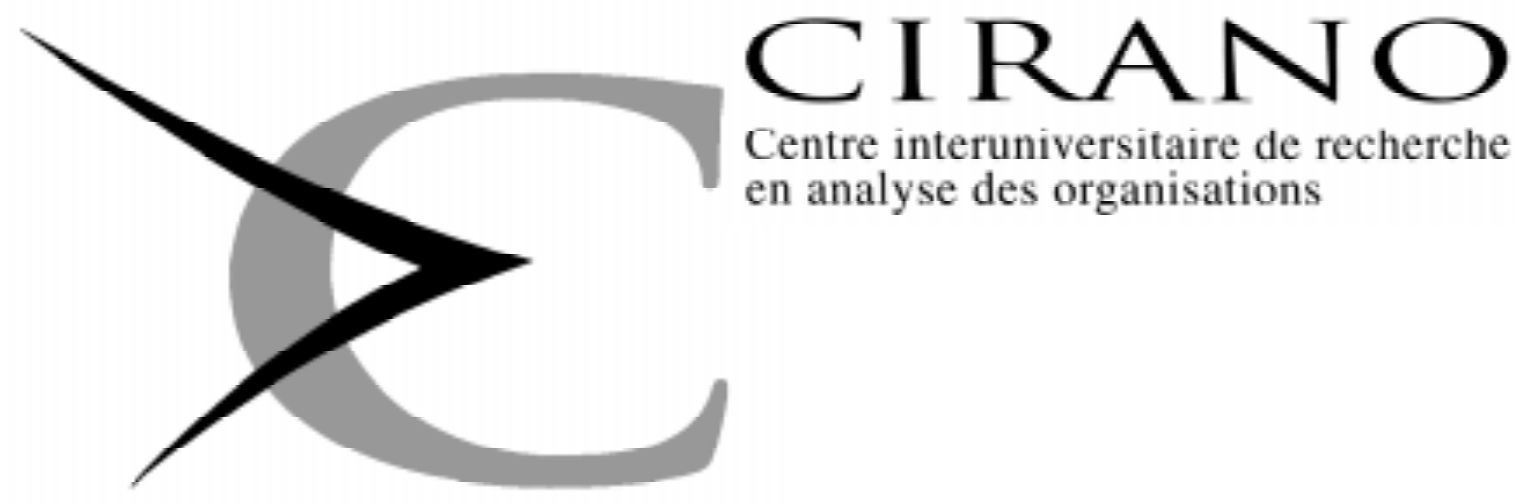

Centre interuniversitaire de recherche en analyse des organisations

Série Scientifique

Scientific Series

96s-01

Cognition in Seemingly Riskless

Choices and Judgments

Louis Lévy-Garboua,

Claude Montmarquette

Montréal

janvier 1996 


\section{CIRANO}

Le CIRANO est une corporation privée à but non lucratif constituée en vertu de la Loi des compagnies du Québec. Le financement de son infrastructure et de ses activités de recherche provient des cotisations de ses organisations-membres, d'une subvention d'infrastructure du ministère de l'Industrie, du Commerce, de la Science et de la Technologie, de même que des subventions et mandats obtenus par ses équipes de recherche. La Série Scientifique est la réalisation d'une des missions que s'est données le CIRANO, soit de développer l'analyse scientifique des organisations et des comportements stratégiques.

CIRANO is a private non-profit organization incorporated under the Québec Companies Act. Its infrastructure and research activities are funded through fees paid by member organizations, an infrastructure grant from the Ministère de l'Industrie, du Commerce, de la Science et de la Technologie, and grants and research mandates obtained by its research teams. The Scientific Series fulfils one of the missions of CIRANO: to develop the scientific analysis of organizations and strategic behaviour.

\section{Les organisations-partenaires / The Partner Organizations}

-Ministère de l'Industrie, du Commerce, de la Science et de la Technologie.

-École des Hautes Études Commerciales.

-École Polytechnique.

-Université de Montréal.

-Université Laval.

-McGill University.

-Université du Québec à Montréal.

-Bell Québec.

-La Caisse de dépôt et de placement du Québec.

-Hydro-Québec.

-Fédération des caisses populaires de Montréal et de l'Ouest-du-Québec.

-Téléglobe Canada.

-Société d'électrolyse et de chimie Alcan Ltée.

-Avenor.

-Service de développement économique de la ville de Montréal.

-Raymond, Chabot, Martin, Paré

Ce document est publié dans l'intention de rendre accessibles les résultats préliminaires de la recherche effectuée au CIRANO, afin de susciter des échanges et des suggestions. Les idées et les opinions émises sont sous l'unique responsabilité des auteurs, et ne représentent pas nécessairement les positions du CIRANO ou de ses partenaires.

This paper presents preliminary research carried out at CIRANO and aims to encourage discussion and comment. The observations and viewpoints expressed are the sole responsibility of the authors. They do not necessarily represent positions of CIRANO or its partners.

\section{ISSN 1198-8177}




\title{
Cognition in Seemingly Riskless Choices and Judgments ${ }^{\star}$
}

\author{
Louis Lévy-Garboua ${ }^{\dagger}$, Claude Montmarquette
}

\begin{abstract}
Résumé / Abstract
En sciences économiques, l'hypothèse que les préférences et les possibilités sont connues et données est largement contredite par des changements peu systématiques observés dans plusieurs expériences et situations réelles. $\mathrm{La}$ conséquence est que la théorie ne semble pas spécifier correctement la rationalité des choix et pose aux économistes plusieurs paradoxes reliés à l'analyse marginale, aux coûts historiques, sur les jugements de justice, sur les effets de dotation ou de statu quo, etc. Dans cette étude, nous concidérons la rationalité cognitive et l'apprentissage dans des situations de choix et de jugements «apparemment» sans risque. Les préférences et les possibilités sont données dans un sens stochastique et elles sont basées sur les anticipations qui sont révisées. La théorie proposée prédit des renversements de préférence dans les expériences et passe avec succès un test économétrique sur données réelles du paradoxe du biais du statu quo.

The assumption of given and known preferences and possibilities so common in economic theory stands in contradiction with the kind of unsystematic change that charaterizes many experimental and real situations. Consequently the theory misspecifies rational choice and generates many puzzles relating to marginal analysis, sunk costs, judgments of fairness, the endowment effect, etc. We instillate rational cognition and learning in "seemingly riskless" choices and judgments. Preferences and possibilities are given in a stochastic sense and based on revisable expectations. The theory predicts experimental preference reversals and passes a sharp econometric test of the status quo bias drawn from a field study.
\end{abstract}

\footnotetext{
* We receive helpful comments from seminar participants at CIRANO (Montréal) and LAMIA (Paris). We thank François Raymond for his excellent research assistance in the empirical part of the paper. The second author gratefully acknowledges the financial support from the FCAR of the government of Québec. The usual disclaimer applies.

${ }^{\dagger}$ Université de Paris I - Sorbonne et LAMIA

* Université de Montréal, CRDE et CIRANO
} 


\section{Unsystematic change and the assumption of given and known possibilities and preferences}

Rational choice theory has been successful in drawing many testable implications from few extremely simple, even unrealistic, normative assumptions. One of these is that the decision-maker's possibilities and preferences are given and known by him prior to his choices. No doubt that the knowledge and constancy of preferences and possibilities is a reasonable assumption for many applications, but it is in no way a prerequisite of rational behavior. Indeed, economic models allow the growth of possibility sets through capital accumulation, and systematic preference changes through rational habit formation and addiction (eg. Becker and Murphy 1988). We study here a broad class of problems in which possibilities and preferences are subject to unsystematic change, but can be said to be given in a stochastic sense. In order to make our argument most clear and uncontroversial, we restrict the present analysis to seemingly riskless choices and judgments, in which final outcomes are stated in a deterministic fashion just before the individual's decision or judgment is sollicited. One of us has extended the argument against given preferences to choices among risky actions (Lévy-Garboua and Blondel 1995).

The point we wish to make in this paper is that cognition plays a hidden but essential role in seemingly riskless situations whenever it is clear that the individual's choice determinants have changed in a way that was unpredictable. A careful scrutiny of the formulation of two characteristic problems may best convey the intuition of the argument. The first question was asked by Tversky and Kahneman (1981) :

«Imagine that you are about to purchase a jacket for (\$125) [\$15] and a calculator for (\$15) [\$125]. The calculator salesman informs you that the calculator you wish to buy is on sale for (\$10) [\$120] at the other branch of the store, a 20minute drive away".

Would you make the trip to the other store?

Subjects reacted quite differently to the two versions of this problem (one with the numbers in parentheses, the other with the numbers in brackets). When the calculator cost $\$ 125$, only $29 \%$ said they would make the trip, whereas $68 \%$ said they would go when the calculator cost only $\$ 15$. This big difference refutes the conventional wisdom of rational choice since the marginal cost of search (a 20-minute drive) and its marginal return (a $\$ 5$ saving on the calculator) are the same for the two versions.

The second question introduces Kahneman, Knetsch and Thaler's (1986) empirical investigation about judgments of fairness: 
«A hardware store has been selling snow shovels for \$15. The morning after a large snowstorm, the store raises the price to $\$ 20$ \%.

Please rate this action as:

Completely Fair Acceptable Unfair Very Unfair

$82 \%$ of respondents considered it unfair or very unfair for the hardware store to take advantage of the short-run increase in demand associated with a blizzard. This kind of «moral» protest questions the economist's faith in price adjustments to clear markets.

Before giving our own interpretation of these answers, we must point out a fundamental dynamic uncertainty inherent to these problems and concealed by the assumption of given and known preferences and possibilities. In these two examples, subjects are informed (by the experimenter) of a $\$ 5$ price change which they could not possibly expect before reading or listening to the question. But the release of unexpected news ruins the fiction of certainty entertained by the conventional wisdom. For, how can you experience a surprise if you are presumed to know the near-future with certainty ? And how could you now feel sure of the last statement when you considered it to be an unexpected rejection of what you believed to be certain immediately before?

A blind application of the given-and-known-preference-and-possibility set assumption would normatively restrict the range of "good reasons" that rational persons effectively look for in making their choices and judgments. In contexts where possibilities and preferences are subject to unsystematic changes, rational learning from similar experiences summarizes an additional set of good reasons which are of utmost importance. In economic words, the omission of bayesian learning by conventional theories of choice runs counter to the rationality postulate, because it is tantamount to supposing that people make less than full use of available information.

Whenever the formulation of the question evokes unpredictable changes of choice determinants, a rational individual should perceive the latter to be stochastic. If it is assumed that data are drawn from a stable stochastic process, the use of anticipated values is more suitable to the rational calculus than current data in seemingly riskless situations. Because there is no way of knowing possibilities and preferences with certainty before the choice, drawing the lessons from past experience and using conditional or revised expectations is the cognitively rational way of deciding.

The famous sentence of Jevons «Bygones are forever bygones» may serve to oppose the normative view of rationality to the cognitive view that we favor. It has two 
facets. One, to which we subscribe, is that rational decisions are forward-looking. The other, that we do not accept, is that the sensations brought about by experience serve the single purpose of supplying instantaneous pleasures and pains and do not convey any valuable information for future decisions. If this view were correct, letting in exogenous stochastic shocks of choice determinants, an outside observer should find successively made choices and judgments to be serially uncorrelated. In actual life, we do not observe that an individual's decisions are made independently over time. We rather observe that learning and memory link successive similar decisions into a continuous chain. Proponents of the given and known preferences and possibilities assumption are obviously aware of learning but they contend that we can reason «as if» that hypothesis was true, after an initial phase of learning. Pareto (1981, chap. 3 ; 145-146) himself suggested this simplification. However, a learning individual will never behave like an omniscient being, in conditions of dynamic uncertainty. To see this, think of your reaction if your computer erased everything that was put into its memory each time you shut it down. If your computer and yourself had unbounded capacities, you would not mind starting the process all over everytime you had to make a new decision. But since capacities are limited, as Simon (1955) put it, it is economical to store software programs and just make marginal adjustments to accommodate new (unexpected) data. Similarly, it is economical to store expectations and just revise them in light of new information, thus making the last decision depend upon accumulated experience.

We shall argue by means of examples that the overreliance of economists and other social scientists on the simple assumption of known and given possibilities and preferences has paved the way for a host of puzzling "preference reversals" in seemingly riskless situations. These have been brilliantly reviewed by Thaler (1987, 1994). The explanation of puzzling behavior deriving from our conception of "cognitive» rationality should be compared to concurrent solutions, of which the most comprehensive are those of Kahneman, Tversky, Thaler and their collaborators. The latter criticize the prevailing normative conception of rationality and propose an eclectic array of modifications, like replacing rationality by quasi-rationality (Thaler 1994), introducing intangible goods in the utility function (Kahneman and Varey 1991), a fairness constraint (Kahneman, Knetsch and Thaler 1986), or ill-behaved utility functions (Tversky and Kahneman 1991). Once cognition and learning are instillated into rational choice theory, there is no more need to postulate some irrationality and complicate the theory so much in order to understand the puzzling choices and judgments in seemingly riskless situations.

The sample of preference reversals examined in this paper concerns cases of violation of the principles of marginal analysis and of the discarding of sunk costs, judgments of fairness, or the endowment effect and status quo bias (section 3). Since 
all these examples are shown from experimental data, we complete the discussion of section 3 by a field study in which these effects also appear nicely and our theoretical explanation can be submitted to an econometric test (section 4). The model of discrete consumer choice with bayesian expectations and learning is first presented in section 2. The main lessons of the paper are summarized in section 5.

\section{Bayesian expectations and consumer discrete choice}

A rational consumer must decide whether to purchase one good in quantity $\mathrm{x} \geq 0$ at price $\mathrm{p} \geq 0$. The other goods consumed in quantity $\mathrm{y}>0$ are taken as numeraire. The time period need not be specified in the present discussion although time is essential for learning because news arrive sequentially and have an investment value. The consumer allocates his wealth $\mathrm{W}$ by maximizing his utility $\mathrm{U}(\mathrm{x}, \mathrm{y})$ under his budget constraint and the non-negativity constraint of the first good:

$$
\begin{array}{ll} 
& \max \mathrm{U}(\mathrm{x}, \mathrm{y}) \\
& \mathrm{x}, \mathrm{y} \\
\text { s.t. } & \mathrm{px}+\mathrm{y}=\mathrm{W} \\
& \mathrm{x} \geq 0
\end{array}
$$

Under the usual concavity assumptions, the first-order condition (necessary and sufficient) for a corner solution $(\mathrm{x}=0)$ is

$$
\mathrm{x}=0 \text { iff } \mathrm{p}^{*} \equiv \frac{\mathrm{MU}_{\mathrm{x}}(0, \mathrm{~W})}{\mathrm{MU}_{\mathrm{y}}(0, \mathrm{~W})} \leq \mathrm{p}
$$

where $\mathrm{MU}_{\mathrm{x}}\left(\mathrm{MU}_{\mathrm{y}}\right)$ stand for the marginal utility of $\mathrm{x}(\mathrm{y})$ when a single unit of the first good is consumed.

Conversely,

$$
x>0 \text { iff } p^{*}>p
$$

The first good is purchased when its reservation price $\mathrm{p}^{*}$ is greater than its market price. The discrete decision can be described by (2) and (3) if all determinants of choice (p, W, U) are given and known with certainty before the choice. But these conditions must be extended to deal with uncertainty by replacing $p^{*}$ and $p$ by their rational expectations using all available information at the time of decision. So, for instance, 


$$
\mathrm{x}>0 \text { iff } \mathrm{E}_{0} \mathrm{p} *>\mathrm{E}_{0} \mathrm{p},
$$

where $\mathrm{E}_{0}$ is the expectation operator at time 0 . The rational expectation coincides with the mean value if it is chosen so as to minimize the variance of forecast error. The last condition can be written most concisely

$$
\begin{aligned}
& \mathrm{x}>0 \text { iff } \mathrm{E}_{0} \mathrm{X}>0 \\
& (=) \quad(\leq)
\end{aligned}
$$

with $\mathrm{X}=\log \mathrm{p}^{*}-\log \mathrm{p}, \quad$ since $\mathrm{p}^{*}>0$ for goods and $\mathrm{p} \geq 0$

The role of cognition and bayesian learning can be introduced in this standard model by viewing $\mathrm{X}$ as a random realization drawn from a stable data-generating process. The distribution of $\mathrm{X}$ is assumed to be normal, of unknown mean EX, and known precision (inverse of variance) $h>0$. The latter assumption is suitable for applications where individuals face exogenous random schocks of price, wealth and utility, and are forced to act as passive, unsystematic, experimenters.

It is further hypothesized that the unknown mean's prior distribution is normal, of known mean $\mathrm{E}_{0} \mathrm{X}$ and precision $\mathrm{k}_{0}>0$. Then, after observing a new realization $\mathrm{X}_{1}$, the posterior mean's distribution is still normal (see, for instance, De Groot 1970), of mean

$$
\mathrm{E}_{1} \mathrm{X}=\frac{\mathrm{k}_{0}}{\mathrm{k}_{0}+\mathrm{h}} \mathrm{E}_{0} \mathrm{X}+\frac{\mathrm{h}}{\mathrm{k}_{0}+\mathrm{h}} \mathrm{X}_{1}
$$

and precision : $k_{1}=k_{0}+h$.

The conventional rational choice model would predict purchase of the first good iff $X_{1}>0$. By contrast, the cognitively rational choice model would make the same prediction iff $E_{1} X>0$. This makes a lot of difference as the forthcoming examples will show. The prior expectation and the current value of $\mathrm{X}$ both contribute to forming the current anticipated value in proportion of their respective precisions.

By iteration of (5) as experience accumulates, it can be shown that expectations become more and more precise and converge in probability towards an history-dependent limit. However, radical innovations may offset the steady state. Reversals of preference are more likely among persons of little experience, and in contexts limiting potential experience like those artificially set by survey questionnaires. 
Several examples of preference reversal form the substance of this paper. In the snow shovel question spelled out in section 1 and in other instances, the prior decision is clearly to buy one good in a specified store, which implies $E_{0} X>0$. The problem is then to predict whether given offsetting news (the price of snow shovels has been increased after the snowstorm) may cause an abrupt change, i.e. $\mathrm{E}_{1} \mathrm{X} \leq 0$. The calculator example of section 1, and questions illustrating the endowment effect (so labelled by Thaler 1980) and the status quo bias (so called by Samuelson and Zeckhauser 1988) address the same issue the other way round: should you make the trip to another store after hearing that the calculator is on sale over there ? should you keep a decorated mug which you probably had no intention of buying but was given to you ? should you accept a unilateral part-time offer by your company which is now employing you full time ? In these instances, the problem is to predict when the unplanned decision (i.e., $\left.\mathrm{E}_{0} \mathrm{X} \leq 0\right)$ can be turned into a good bargain $\left(\mathrm{E}_{1} \mathrm{X}>0\right)$.

\section{Preference reversals}

Over recent years, psychologists and economists have realized simple experiments which systematically refute the basic tenets of rational choice in seemingly riskless situations. Moreover, a vast proportion of respondents often make the same puzzling choice or judgment, although they are bound to make independent decisions. The last finding is especially interesting from a sociological perspective. It suggests that a good answer should not rely too much on personal tastes, given the great diversity of tastes.

The cognition-based theory of choice laid down in the previous section will be used systematically to solve a number of puzzles. Let us rewrite equation (5) slightly differently:

$$
\mathrm{E}_{1} \mathrm{X}=\mathrm{E}_{0} \mathrm{X}+\frac{\mathrm{h}}{\mathrm{k}_{0}+\mathrm{h}} \mathrm{S}
$$

in which $\mathrm{S} \equiv \mathrm{X}_{1}-\mathrm{E}_{0} \mathrm{X}$ captures the overall surprise brought about by new information arising at time 1 and unexpected at time 0 . The theory predicts that preference reversals will never occur when the prior forecast is fulfilled $(S=0)$, and, more generally, when the surprise "confirms" the prior. They are only possible if surprises have an offsetting effect, either when $\mathrm{E}_{0} \mathrm{X} \leq 0$ and $\mathrm{S}>0$, or $\mathrm{E}_{0} \mathrm{X}>0$ and $\mathrm{S}<0$. The magnitude of $\frac{\mathrm{h}}{\mathrm{k}_{0}+\mathrm{h}} \mathrm{S}$ in absolute terms conditions the likelihood that 
an offsetting surprise induce a preference reversal. The surprise effect on posterior expectations is dampened by a positive coefficient $\frac{\mathrm{h}}{\mathrm{k}_{0}+\mathrm{h}}<1$.

In the following examples, prior expectations and current news are easily described. For the most part, exogenous price and wealth surprises are being considered.

\subsection{Marginal analysis}

The calculator example shown in section 1 illustrates the refutation of marginal analysis. People seem to make a confusion between average and marginal costs, since they are willing to make a trip to another store to save $\$ 5$ on a cheap calculator ( $\$ 15)$, but refuse to do that when the calculator is expensive [ $\$ 125]$.

The prior expectation must be such that

$$
\mathrm{E}_{0} \mathrm{X}(\text { store } 1)>0 \quad \text { and } \quad \mathrm{E}_{0} \mathrm{X}(\text { store } 2) \leq 0 \text {, }
$$

since the subject is supposed to have agreed purchasing the calculator along with a jacket in store 1 , but not in store 2 . On hearing that he may save $\$ 5$ on the price of the calculator if he makes the trip to store 2, he feels good surprises both in price and real wealth. The cost of travel can be omitted without loss of generality, as long as the individual makes a net saving. The overall surprise is simply

$$
\mathrm{S}=\log \frac{\mathrm{p}^{*}(\mathrm{~W}+5)}{\mathrm{p}^{*}(\mathrm{~W})}-\log \frac{\mathrm{p}-5}{\mathrm{p}}>0
$$

It is safely assumed here that $\$ 5$ is a small amount in comparison to wealth so that the wealth effect is small too. The price effect is a function of the relative price rebate. Therefore, the smaller is the calculator's price, the nicer is the surprise, and the more subjects are inclined to make the trip for a given prior. The theoretical prediction conforms to the results from Tversky and Kahneman (1981), also presented by Thaler (1994; 13-15). 


\subsection{Sunk costs}

Fixed, historical, and other sunk costs should not influence current decisions according to the conventional wisdom: bygones are forever bygones. However, Tversky and Kahneman (1981) report two experiments (see also Thaler 1994 ; 149) where theory predicts a single behavior but subjects exhibit widely divergent responses: in the former, sunk costs are ignored; while in the latter, they are not. First imagine that you have decided to see a play, and the admission price is $\$ 10$. As you enter the theater you discover that you have lost a $\$ 10$ bill. Would you still pay $\$ 10$ and see the play? $88 \%$ of the respondents answered yes to that question. Now imagine as you enter the theater you discover that you have lost your $\$ 10$ ticket. The seat was not marked and the ticket is not refundable. Here, only $46 \%$ of the respondents would accept to pay another $\$ 10$ to purchase a new ticket and see the play. These conflicting choices contradict the economic perception that money should be allocated to the activity that yields the greatest marginal utility, which is obviously independent of whether you lost a $\$ 10$ bill or a $\$ 10$ ticket.

The explanation of our cognition-based theory runs as follows. The outset of both experiments being the same, $\mathrm{E}_{0} \mathrm{X}$ must have the same positive value. Thus, divergent responses require divergent surprises. This is truly what happens. Subjects only experience a bad wealth surprise if they lose a $\$ 10$ bill

$$
\mathrm{S}=\log \frac{\mathrm{p}^{*}(\mathrm{~W}-10)}{\mathrm{p} *(\mathrm{~W})}<0
$$

but also a bad price surprise (i.e., the actual price of theater has doubled) if they lose a $\$ 10$ ticket

$$
\begin{gathered}
\qquad \mathrm{S}^{\prime}=\mathrm{S}-\log 2<\mathrm{S} \\
\text { While } \frac{\mathrm{h}}{\mathrm{k}_{0}+\mathrm{h}} \mathrm{S} \text { may be too small to outweigh } \mathrm{E}_{0} \mathrm{X} \text {, this is less likely to }
\end{gathered}
$$

occur in the second case.

Other striking examples of the influence of sunk costs on current decisions have been reported by Thaler $(1980,1987$; 112) and Arkes and Blumer (1985). They found that the attendance to a baseball game or theater plays was significantly more regular when the spectator had bought his tickets full price than when he had got them free or with a discount. The two groups of subjects are facing the same objective 
surprises but those who purchased their tickets full price have on average more taste, or greater "subjective quality" expectation (on this notion, see Lévy-Garboua, Montmarquette 1995a), so that their marginal rate of substitution between the live show and other goods should be less responsive to exogenous changes. The subjective surprise would then be smaller in absolute terms for the first group of live show lovers.

Interestingly, Arkes and Blumer (1985) noticed that the sunk cost effect fades away in the long run. Attendance to the first five plays of a season of ten plays was significantly reduced by the price discounting, but this effect was not significant for the second half of the season. This last observation is fully consistent with a theory of bayesian learning which predicts a stochastic convergence of expectations and less preference reversals as subjects gain experience.

The cognitively rational behavior supports Thaler's $(1980,1987 ; 112)$ intuition that "one reason sunk costs are not ignored is that costs that have not been mentally amortized are coded as losses". Mental accounting is a way of making successive decisions depend on one another. However, a theory that is deeply-rooted in the rational choice framework has virtues of generality and parsimony which keep social scientists safe from the dangers of unverifiable introspection.

\subsection{Judgments of fairness}

Cognitive rationality is also useful in explaining personal judgments. In two companion papers, we apply the theory to predict judgments of satisfaction that people make about their own prior choices, like going to see a play and choosing a job (LévyGarboua, Montmarquette 1995a, 1995b). We deal here with judgments of fairness, like the question from Kahneman, Knetsch and Thaler (1986) reproduced in the introductive section. These authors argue that considerations of fairness restrict the actions of profit-seeking firms, notwithstanding the fact that firms that behave unfairly are punished in the long run. Frey and Pommerehne (1993) have replicated their study on german and swiss samples. They further note (p. 297) that a rise in price to cope with an excess demand is considered less unfair "in a recurrent, predictable situation in which supply may increase" than "in a unique, unexpected setting characterized by a high degree of uncertainty".

In our view, judgments of fairness express the reaction of individuals who are deprived of their prior potential choice by an unexpected detrimental move of the trading partner like a price rise or a wage reduction. Given one's prior choice to buy a snow shovel for $\$ 15$, i.e. $E_{0} X>0$, a $\$ 5$ price increase is a bad surprise $(S<0)$ which 
may entail a change of decision, like simply refusing to buy or buying in another store at a lower price, i.e. $\mathrm{E}_{1} \mathrm{X} \leq 0$. Once again, the theory makes the correct prediction that this kind of reaction will fade away in the long run.

Moreover, the sensation of unfair treatment should be specific to the particular good that individuals had planned to purchase, or to the particular store where they intended to make this purchase. The reason is, like in the calculator example of 3.1, that $\mathrm{E}_{1} \mathrm{X} \leq 0$ only indicates that a specific good in a specific place will not be purchased, but does not prelude purchase of a substitute item or of the same good in another place. This prediction is corroborated by Frey and Pommerehne's (p. 304-305) observation that a price increase is considered no more acceptable when consumers can easily switch to another good or to another supplier. Rationing goods in excess demand ("first come, first served") does not suffer from the same defect. The price remains as expected, but no one can help if the stock of snow shovels has been exhausted. After all, the hardware store cannot be blamed for not being cleverer at forecasting snowstorms than its customers, given the fact that a stock increase would probably raise storage costs and retail prices.

Finally, our theory easily explains why firms do not need costly enforcement procedures for holding to predictable, or "rigid", prices and wages. The anticipation of their trading partners' "exit" response to their own discretionary moves is a strong built-in incentive. The sole prediction of the induced demand reduction may prevent firms which maximize long run profits from raising their short run profits at their partners' expense.

\subsection{The endowment effect and status quo bias}

The effect of ownership on value is called the endowment effect (Thaler 1980). The value that an individual assigns to a good appears to increase substantially and immediately after the good is given to the individual. It is viewed as an embarrassment for the given and known preference assumption. A closely related phenomenon is the status quo bias, of which Knetsch and Sinden (1984) offer compelling evidence (Tversky and Kahneman 1991 review more studies on this question). Students are asked to answer a brief questionnaire. Students from one class receive a decorated mug as compensation. The students from the other class receive a large bar of Swiss chocolate. At the end of the session, both gifts are shown to all students and they are invited to trade. Despite the evident low transaction cost, approximately $90 \%$ of the participants retain their initial gift. 
The endowment effect and status quo bias are consistent with cognitive rationality. Since the students involved in the experiment probably did not plan to purchase a decorated mug (a bar of Swiss chocolate), their prior expectation is such that: $\mathrm{E}_{0} \mathrm{X} \leq 0$. Provided the mug (chocolate) is a good for them, this present was a good surprise: $X_{1}=+$ because $p_{1}=0$. Consequently, the weighted average of $E_{0} X$ and $\mathrm{X}_{1}$ (equation (5)) yielding the posterior expectation $\mathrm{E}_{1} \mathrm{X}$ must be positive even if the precision of the unknown mean $h$ is much smaller than that of prior mean $k_{0}$. The change of sign between $\mathrm{E}_{0} \mathrm{X}$ and $\mathrm{E}_{1} \mathrm{X}$ reflects the status quo bias. Subjects have a tendency to keep what they own and not acquire what they do not own.

Furthermore, the pleasure produced by the gift is propagated to the expectation of future pleasures to be derived from the good's consumption. This is a consequence of our assumption of unknown preferences, because ignorant potential consumers must rely on indirect information, like price discounts, reputation, uninformative or informative advertising, to assess their willingness to pay (an early discussion of the implications of unknown preferences can be found in Lévy-Garboua 1979). Thus, there will be an informational asymmetry between potential sellers (who rely on indirect information and own experience) and potential buyers of the good. Since good suprises are associated to consumption of the good in the reported experiments, the selling price will be greater than the buying price, which is the endowment effect.

\section{Endowment effect and status quo bias in a "worktime reduction program": an empiriral study}

A recent experience of "job sharing" by a major Canadian utilities company offers a novel illustration of the power of the endowment effect and status quo bias in real settings. The canadian company had to reduce its labor force by a substantial number. Early retirements, temporary leaves of absence, and a worktime reduction program were the options offered by the company to its employees to avoid permanent layoffs. In early December 1993, the company sent a questionnaire to all employees and asked them to respond to the different options proposed. All employees were informed individually of their own financial costs in choosing any particular option. Responding to the questionnaire was voluntary. The worktime reduction program included less statutory holidays and a four-day work week. For the group of 4480

workers (technicians) concerned here, the anticipated average income loss varied from 
$7 \%$ to $13 \%$ of their total labor income following different scenarios ${ }^{1}$. In figure 1 , we report (top) the number and percentage of individuals choosing the different options. $649(14.5 \%)$ only declared their interest for the worktime reduction program. The vast majority, 3550 (79.2\%), of the workers, however, declined to respond to the questionnaire or flatly rejected the worktime reduction program in specific comments.

Shortly after this survey, however, the company and the workers' union agreed to implement a worktime reduction program that implied a $7.6 \%$ average income reduction.

\section{[Insert Figure 1, about here]}

A few months later, the company found it difficult to manage its repair and service operations under the new program. The company sent a new questionnaire and offered all technicians to return to the pre-program conditions. At the bottom of Figure 1, the responses of the technicians are reported conditional on their responses to the first questionnaire. It is observed that, after experimentation, the workers that initially chose not to respond to the first questionnaire or rejected the program did not maintain their preference. Specifically, $83.8 \%$ of these workers refused after experimentation to return to the pre-program conditions!

These intriguing responses offer a neat illustration of the endowment effect and status quo bias from a field study. Samuelson and Zeckhauser (1988) used the same methodology to examine the choice of medical plans by Harvard employees. Like them, we observe that small changes to the status quo were favored by the workers' union over larger changes. The negotiated $7.6 \%$ average income reduction lies at the bottom of the interval of reductions offered by the company. The novel feature of our field study is that the status quo bias is made to work successively in two opposite directions because the company, after implementing its worktime reduction program, changed its mind and wished to come back to the initial situation of full time work. This produces cyclic preferences such that $\mathrm{A}$ is first preferred to $\mathrm{B}$, then after experimentation $\mathrm{B}$ is preferred to $\mathrm{A}$.

The specificity of this field study will be exploited in the subsequent econometric study. Before proceeding, we acknowledge that our analysis partly ignores strategic considerations and commitment to prior choices which may also explain the status quo bias.

\footnotetext{
${ }^{1}$ One scenario was that the Government of Canada would accept to compensate part of the income loss with funds from the Federal unemployment insurance program.
} 
Workers are divided in two groups, those accepting to participate to a worktime reduction program (649) and those initially refusing to answer the company's questionnaire or explicitly rejecting the program (3550). A small third group of individuals taking leave of absence or retiring (281) have made a precommitment to leave and have no choice of returning to their job after a few months.

The first group is composed of workers who planned to work part time under less advantageous conditions than proposed by the company. The discrete choice model stipulates that $\mathrm{E}_{0} \mathrm{X}>0$ for these workers. Presumably, they had gathered enough information about the merits of extra leisure and household production, or not having to travel to work so often, to offset the status quo bias. Workers who experience the strongest status quo bias form the second group. For ther latter, $\mathrm{E}_{0} \mathrm{X}^{\prime} \leq 0$ and information about the advantages of worktime reduction is likely to be scarce. The fact that a vast majority of this group refused to return after experimenting part-time work is persuasive evidence that they were not fully informed initially and got good surprises on the whole.

Our model also predicts that the determinants of their second period choice be uncorrelated to those of their first period choice, since the former could not be forecast by them with the information available in the initial situation. The same prediction applies to both groups of workers. At the core of an econometric test of the model are the "surprises" of the experimentation, an element which is not easily measured by an outside observer (say the econometrician). People experience the surprises, but the econometrician must infer them. The latter needs to estimate people's expectations and compare them with their realizations over a period of time. An alternative is to ask directly each respondent about his anticipations and surprises. No direct question of this kind is available in the present survey. On the other hand, to model the expectations of the technicians about the expected net benefits or costs of the worktime reduction program would require data on household income, time to travel to work, age and number of children in the family, mortgage monthly payment, etc. These data are not available either.

Nevertheless, a sharp test of the model can be achieved with a bivariate probit sample selection model applied to each pair of first and second period decisions. Probit analysis is particularly well-suited here because expectations are assumed to follow stable normal distributions. For example, for the first period decision (see Figure 1), consider the following binary choice: one for a participation decision and zero for all potential alternatives. Next participants (who form the first group) are nonrandomly selected in the sample and their second period binary choice is one for refuse to return and zero for return. This is the case of the technicians of the 
first group who should largely reconfirm their initial choice of participating to the worktime reduction program. For the other group of interest, the first period binary choice is one for refusing to answer or rejecting the program and zero otherwise. Then the second group of non-particpants is nonrandomly selected and the second period binary choice is one for return and zero for refuse to return. Maximum likelihood estimation of the bivariate probit model with selectivity bias yields simultaneous estimates of all the decision parameters including a correlation coefficient estimate between the error terms of the two period decisions ${ }^{2}$.

The error terms of each period decision capture unmeasured or unspecified determinants of the corresponding choice. Since all determinants of choice should be uncorrelated between periods, the correlation coefficient estimate between period 1 and period 2 residuals is expected to be nil. The prediction of the model is also tested by the bivariate probit method.

The determinants of period choices are the worker's age and marital status, education level (measured by dummy variables of primary, secondary and postsecondary education), and years of tenure in the company and its square (TEN, TEN2). Interaction variables included age times worker's level of education and the worker's wage times years of tenure (WAGE*TEN) ${ }^{3}$. The results in the first column of Table 1 indicate that the divorced and the more experienced technicians were less likely to participate to the worktime reduction program. The coefficients of four variables were statistically significant, three at the $1 \%$ level and one at the $10 \%$ level. No variable was statistically significant for the second period choice (column 2 of Table 1), which is consistent with the prediction that the determinants of choice be uncorrelated between periods and that workers from the first group be well informed of the consequences of their decision.

[Insert Table 1, about here]

In column 3, we report the results for the group of technicians who initially refused to answer or rejected the program. The results are coherent with those reported in the first column: older technicians are more likely to choose to retire or

\footnotetext{
${ }^{2}$ The estimations were done with LIMDEP. Technical details about the sample selection bivariate probit model are discussed in Greene (1992).

${ }^{3}$ The technicians from an homogenous group. $98.2 \%$ are male and $73.0 \%$ have a secondary level of education. The average age is 40.6 years with a 17.6 average years of tenure. Although wages vary with experience, the distribution is highly centered around the mean : in 1993, the mean wage of technicians was $\$ 47857$ with a standard deviation of \$2 795 .
} 
participate to the program, except for the better paid. Here four coefficients are statistically significant at the $1 \%$ level and one at the 5\% level. For the second period choice only one variable (excluding the intercept term) was statistically significant at the $1 \%$ level but was not significant in the first period choice. Second period choice determinants are still uncorrelated to first period determinants. The only exception is for divorced workers who reject the program and accept to return, perhaps because they are strongly precommitted to supporting the financial burden of their family situation.

Lastly, we find no correlation between the two period residuals for none of the two groups, as predicted by the theory.

\section{Conclusion}

We have argued that the rational choice model used by economists excessively relies on the unnecessary assumption of given and known preferences and possibilities. Logically, the latter is in contradiction with the kind of unsystematic change or dynamic uncertainty that characterizes many experimental and real situations. We labelled such cases as seemingly riskless choices and judgments. The standard assumption is often counterfactual in seemingly riskless situations because it does not explain the kind of stochastic dependence between successive decisions that is commonly observed. Such cases include refutations of marginal analysis, influence of sunk costs on current decisions, judgments of fairness, or the endowment effect and status quo bias.

The given-and-known-preferences-and-possibilities assumption seems so simple and compelling that previous generalizations like Tversky and Kahneman's (1991) theory of reference-dependent choices and Thaler's (1994) quasi-rationality concept have questioned the rationality postulate, the nature of goods and constraints, and the form of the utility function rather than address this issue. However, cognitive rationality and the model of bayesian expectation formation and learning that we suggested appear to be a simpler and more natural theory of reference-dependent choices which provides a unified explanation of many instances of preference reversal within the rational choice framework. In all the examples considered, the prior is reasonably well specified and constitutes a natural reference. Also, bayesian learning and the normality of the decision variable stem from basic statistical theory while the

ill-behaved form of the utility function implied by "loss aversion" was first conceived as a post factum generalization (Kahneman and Tversky 1979). 
A theory of rational choice which is based on cognition and learning is also interesting from a sociological perspective. First, it shows that choices and judgments may be shared by a vast majority of non interacting agents of widely different tastes because the latter are homogeneized in predictable directions, in the short run, by unsystematic objective changes. Second, by stating that sensations have an informational value in seemingly riskless situations, it may establish a bridge between the so-called "hot" and "cold" theories of action. 


\section{REFERENCES}

Arkes, H.R., and C. Blumer (1985). "The Psychology of Sunk Cost", Organizational Behavior and Human Decision Processes 35: 124-140.

Becker, G.S., and K.M. Murphy (1988). "A Theory of Rational Addiction", Journal of Political Economy 96: 675-700.

De Groot, M.H. (1970). Optimal Statistical Decisions, New York: Mac Graw Hill.

Frey, B.S., and W.W. Pommerehne (1993). "On the Fairness of Pricing - An Empirical Survey among the General Population", Journal of Economic Behavior and Organization 20: 295-307.

Greene, W.H. (1992). LIMPED User's Manual and Reference Guide, version 6.0, Bellport: Econometric Software, Inc.

Kahneman, D., Knetsch, K., and R. Thaler (1986). "Fairness as Constraint on Profit Seeking: Entitlements in the Market", American Economic Review 76: 728741.

Kahneman, D. and A. Tversky (1979). "Prospect Theory: An Analysis of Decisions under Risk", Econometrica 47: 263-291.

Kahneman, D. and C. Varey (1991). Notes on the Psychology of Utility, p. 127-163. In J. Elster and J.E. Roemer (ed.), Interpersonal Comparaisons of WellBeing, Cambridge: Cambridge University Press.

Knetsch, J.L., and J.A. Sinden (1984). "Willingness to Pay and Compensation Demanded: Experimental Evidence of an Unexpected Disparity in Measures of Value", Quarterly Journal of Economics 94: 507-521.

Lévy-Garboua, L. (1979). Perception and the Formation of Choice, p. 97-121. In L. Lévy-Garboua (ed.), Sociological Economics, London: Sage Pub.

Lévy-Garboua, L., and C. Montmarquette (1995a). "Une étude économétrique de la demande de théâtre sur données individuelles", Economie et Prévision, Forthcoming. 
Lévy-Garboua, L., and C. Montmarquette (1995b). "Reported Job Satisfaction: What Does It Mean?" Unpublished Manuscript. Lamia, University of Paris I (Panthéon-Sorbonne) and CRDE, University of Montreal and CIRANO.

Lévy-Garboua, L., and S. Blondel (1995). "La décision comme argumentation", Lamia, Paris I. Paper presented at the Conference "La dimension cognitive dans l'analyse sociologique" at Paris - Sorbonne, May 4-5.

Pareto, V. (1981). Manuel d'Economie Politique, 5th edition, Genève: Droz (first French edition, 1909).

Samuelson, W., and R. Zeckhauser (1988). "Status Quo Bias in Decision Making", Journal of Risk and Uncertainty 1: 7-59.

Simon, H. (1955). Models of Man, New York: Wiley.

Thaler, R.H. (1980). "Toward a Positive Theory of Consumer Choice", Journal of Economic Behavior and Organization 1: 39-60.

Thaler, R.H. (1987). The Psychology of Choice and the Assumption of Economics, pp. 99-130. In A. Roth (ed.), Laboratory Experiments in Economics: Six Points of View, New York: Cambridge University Press.

Thaler, R.H. (1994). Quasi Rational Economics, New York: Russel Sage Foundation.

Tversky, A., and D. Kahneman (1981). "The Framing of Decisions and the Psychology of Choice", Science 211: 453-458.

Tversky, A., and D. Kahneman (1991). "Loss Aversion in Riskless Choice: A Reference-Dependent Model", Quarterly Journal of Economics 106: 10391061. 
Figure 1 : Sequential Choice to a Worktime Reduction Program

\begin{tabular}{l|l|l|l|}
\hline \multicolumn{1}{c|}{} & \multicolumn{2}{|c|}{ TECHNICIANS } \\
4480
\end{tabular}


TABLE 1

\section{DETERMINANTS TO A WORIKTIME REDUCTION PROGRAM (Bivariate Probit with Selectivity Bias)}

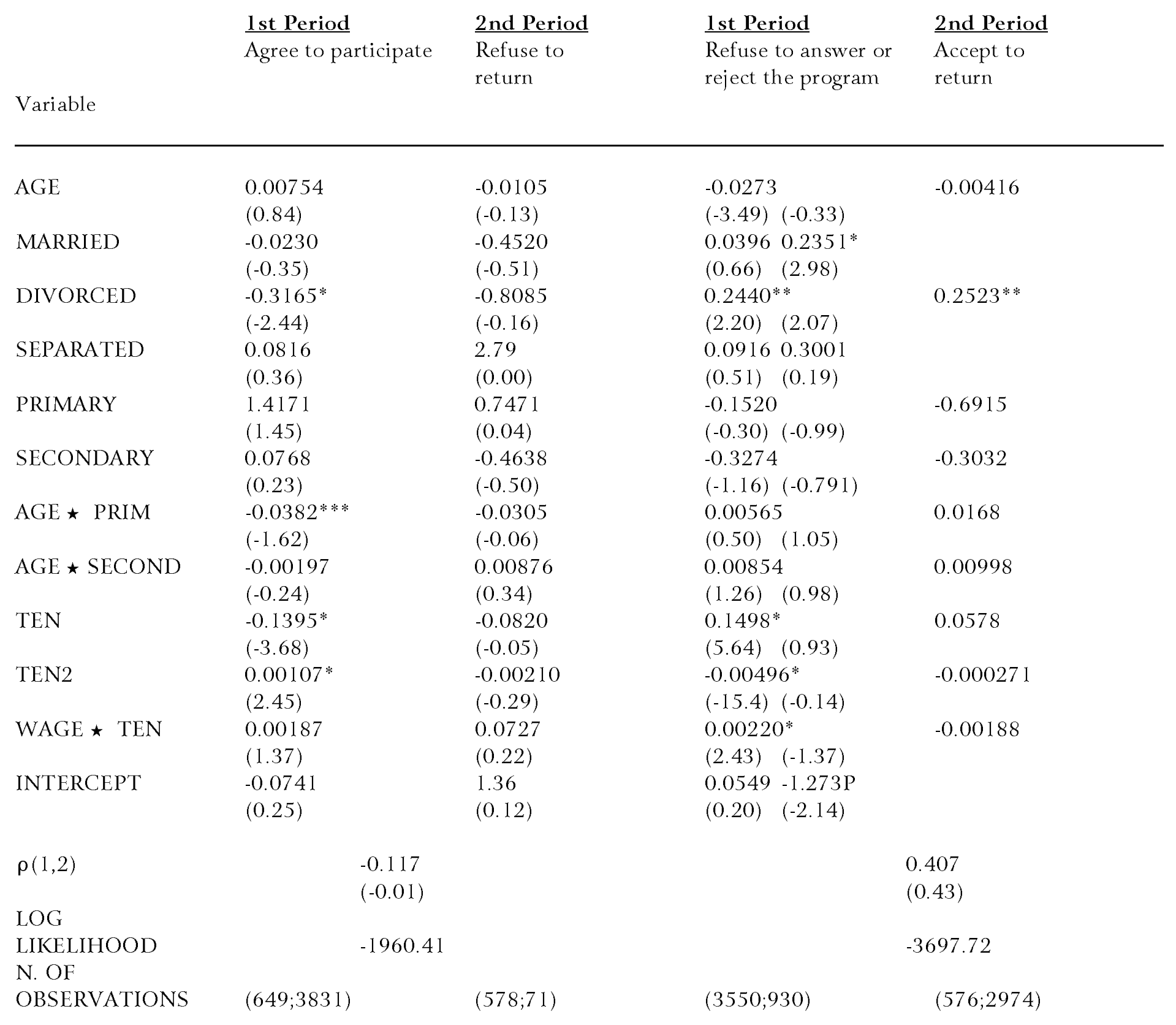

$\bar{t}-$ statistics are in parentheses

* Significant at 0.01

* Significant at 0.15

*** Significant at 0.10 


\title{
Liste des publications au CIRANO
}

\author{
Série Scientifique / Scientific Series (ISSN 1198-8177)
}

\author{
96s-01 Cognition in Seemingly Riskless Choices and Judgments / Louis Lévy-Garboua et Claude \\ Montmarquette \\ 95s-51 Entry Blockading Locations / Marcel Boyer, Philippe Mahenc et Michel Moreaux \\ 95s-50 Environmental Protection, Producer Insolvency and Lender Liability / Marcel Boyer et \\ Jean-Jacques Laffont \\ 95s-49 Stochastic Volatility / Eric Ghysels, Andrew Harvey et Eric Renault \\ 95s-48 Is Workers' Compensation Disguised Unemployment Insurance? / Bernard Fortin, Paul \\ Lanoie et Christine Laporte
}

95s-47 Asset and Commodity Prices with Multiattribute Durable Goods / Jérôme Detemple et Christos I. Giannikos

95s-46 Cohort Effects and Returns to Seniority in France / David N. Margolis

95s-45 Costs and Benefits of Preventing Workplace Accidents : Going from a Mechanical to a Manual Handling System / Paul Lanoie et Louis Trottier

95s-44 Estimating and Testing Exponential-Affine Term Structure Models by Kalman Filter / JinChuan Duan et Jean-Guy Simonato

95s-43 Empirical Martingale Simulation for Asset Prices / Jin-Chuan Duan et Jean-Guy Simonato

95s-42 Trading Patterns, Time Deformation and Stochastic Volatility in Foreign Exchange Markets / Eric Ghysels, Christian Gouriéroux et Joanna Jasiak

95s-41 Testing the Option Value Theory of Irreversible Investment / Tarek M. Harchaoui et Pierre Lasserre

95s-40 Vertical Integration, Foreclosure and Profits in the Presence of Double Marginalisation / Gérard Gaudet et Ngo Van Long

95s-39 On the Dynamic Specification of International Asset Pricing Models / Maral kichian, René Garcia et Eric Ghysels

95s-38 Costs and Benefits of Preventing Worplace Accidents: The Case of Participatory Ergonomics / Paul Lanoie et Sophie Tavenas

95s-37 Dynamic Incentive Contracts with Uncorrelated Private Information and History Dependent Outcomes / Gérard Gaudet, Pierre Lasserre et Ngo Van Long

95s-36 Some Results on the Markov Equilibria of a class of Homogeneous Differential Games / Ngo Van Long et Koji Shimomura

95s-35 Capacity Commitment Versus Flexibility : The Technological Choice Nexus in a Strategic Context / Marcel Boyer et Michel Moreaux

95s-34 Signaling in Financial Reorganization : Theory and Evidence from Canada / par Jocelyn Martel

95s-33 Real Investment Decisions Under Information Constraints / par Gérard Gaudet, Pierre Lasserre et Ngo Van Long

95s-32 Market Time and Asset Price Movements Theory and Estimation / par Eric Ghysels, Christian Gouriéroux et Joanna Jasiak

95s-31 Stochastic Volatility and Time Deformation : An Application to Trading Volume and Leverage Effects / par Eric Ghysels et Joanna Jasiak 